\title{
ZNAKI SAMOTNOŚCI. JEZZYKOWY WYMIAR WYJĄTKOWEGO DESYGNATU
}

Katarzyna Sobstyl, Samotność i jej obrazy w języku,

Wydawnictwo Uniwersytetu Marii Curie-Skłodowskiej, Lublin 2014.

Samotność z powodzeniem określić można mianem fenomenu kulturowego, uczucia lub stanu. Prace jej poświęcone publikują psychologowie, socjologowie, filozofowie czy antropologowie, nakreślając jej charakterystykę w sobie właściwiej optyce i eksponując wybrane jej aspekty. Czy możemy więc mówić o pełnym obrazie samotności w literaturze przedmiotu? Opublikowana w 2013 roku książka Samotność i jej obrazy w języku zdaje się udzielać odpowiedzi negatywnej, dopiero bowiem wraz z jej ukazaniem się, badania nad zjawiskiem samotności zyskują na kompleksowości.

Autorka, jak sugeruje już sam tytuł pracy, bada samotność w perspektywie językoznawczej, usiłując, w znakomitej większości przypadków z powodzeniem, uchwycić jej istotę poprzez językowe zapośredniczenia. Innymi słowy, bada, jak samotność przegląda się w języku i jak ten ją oddaje. Można by w tym miejscu przywołać szeroką dyskusję problemu referencjalności znaków językowych, precyzji referencjalnej elementów systemu językowego, można by też zrekonstruować cały pejzaż teorii i koncepcji lingwistycznych i semiotycznych, włączając te najbardziej skrajne, na przykład o arbitralności bądź nieumotywowaniu znaku językowego, nieobecności odniesienia przedmiotowego czy też nieadekwatności wyrażeń. Nie ma to jednak $\mathrm{w}$ tym miejscu waloru rozstrzygającego i nie jest konieczne dla prowadzenia rozważań, więcej nawet - dobrze, że autorka nie zagłębia się w te kwestie, gdyż nie taki cel przyświeca jej wysiłkowi. Pisząc o tym ostatnim, należy zauważyć niemały trud, jaki podjąć musiała Katarzyna Sobstyl, by 
przeprowadzić swoje badania. Pochylając się bowiem nad fenomenem samotności w języku, autorka pracowała na - mówiąc najprościej - dwóch rodzajach danych: zastanych i wtórnych, wytworzonych. Do pierwszych zaliczyć trzeba dane leksykograficzne, na które składają się te zaczerpnięte ze słowników, przysłów i konkretnych użyć słowa "samotność”, do drugich z kolei materiał zebrany za pomocą ankiet i analizowany metodą ilościową. Takie dobranie źródeł danych i ich analizy już przesądza o kompleksowym potraktowaniu przedmiotowego zagadnienia i jest właściwe celowi, jaki autorka sobie postawiła, a którym jest, sprecyzujmy, "przybliżenie złożonego obrazu SAMOTNOŚCI zgodnie z metodologią językowego obrazu świata, na podstawie danych językowych pochodzących z kilku wybranych źródeł”1. Przywołajmy jeszcze jedną uwagę autorki: „Interesujące jest więc, czy rozważania zawarte $\mathrm{w}$ opracowaniach naukowych znajdą swoje potwierdzenie $\mathrm{w}$ obrazie SAMOTNOŚCI utrwalonym w języku. Chodzi nie tylko o to, jak samotność definiują opracowania leksykograficzne języka polskiego, ale także o to, jaki jej obraz wyłania się z wypowiedzi użytkowników języka"2.

Nie mam na celu referowania treści książki i wniosków, do jakich dochodzi Sobstyl, zamiast tego odnotuję wybrane kwestie zajmujące autorkę. Rozpoczyna ona mianowicie od przedstawienia stanu badań nad samotnością z obszaru nauk społecznych i humanistycznych. Za uzasadnioną i udaną uznać należy decyzję, by nie poświęcać nadto uwagi i miejsca szczegółowemu analizowaniu poszczególnych koncepcji filozoficznych, psychologicznych, z zakresu psychologii społecznej, socjologii czy pedagogiki. W zamian autorka proponuje możliwie szeroki przegląd tychże stanowisk, nie pomijając istotnego rozróżnienia na samotność i osamotnienie, wprowadzając figurę singla oraz wskazując najważniejsze ustalenia ich dotyczące. $W$ rozdziale drugim, zatytułowanym "Założenia metodologiczne pracy. Stan badań językoznawczych", Sobstyl, po pierwsze, rozwija nadrzędne tu pojęcie językowego obrazu świata, oraz, po drugie, prezentuje stan językoznawczych badań nad ujmowaniem samotności, zarówno ten czysto słownikowy, jak i ujęty w przysłowiach. Zatrzymajmy się na moment przy pojęciu językowego obrazu świata, które zdaje się dla autorki pojęciem-matrycą, porządkującym całość wywodu. Jak sama przyznaje, pojęcie to towarzyszy różnym koncepcjom i autorzy rozmaicie je wykorzystują, co jednak najbardziej istotne: „rozwijająca się koncepcja JOS [skrót autorki - przyp. K.M.] pozwoliła na

${ }^{1}$ K. Sobstyl, Samotność i jej obrazy w języku, Wydawnictwo Uniwersytetu Marii Curie-Skłodowskiej, Lublin 2014, s. 12; wersaliki autorki.

2 Ibidem, s. 35; wersaliki autorki. 
wykształcenie metod badawczych zgodnych w wielu punktach z metodologią lingwistyki kognitywnej, również zajmującej się opisem języka uwikłanego w kontekst kulturowy i badaniem, w jaki sposób w języku zostaje odzwierciedlona rzeczywistość" 3 . Takie jednoznaczne zwrócenie uwagi na relacje języka i kultury, na językowe odzwierciedlanie rzeczywistości kulturowej, profilowanie kulturowe i tekstotwórcze, czyni pracę w mocnym znaczeniu humanistyczną, i rzeczywiście - perspektywa językoznawstwa humanistycznego jest zachowana w całym tomie. Co jednak najbardziej mnie zainteresowało, to użycie tutaj słowa „obraz”, które w analizach lingwistycznych szczególnie się wyróżnia. Dychotomiczne ujmowanie obrazu i tekstu, wizualności i języka, figury i dyskursu jest silnie zakorzenione $\mathrm{w}$ naukach humanistycznych mimo podejmowanych $\mathrm{z}$ mniejszym bądź większym powodzeniem prób jego przezwyciężania. Tutaj jednak mamy do czynienia z sytuacją szczególną, gdyż autorka, pisząc jednoznacznie z perspektywy lingwistycznej, przywołuje pojęcie obrazu. Rzecz jasna, językowy obraz świata jest "gotowym” wyrażeniem i trudno wskazywać w nim ślady wspomnianej dychotomii, jednak już w stwierdzeniu: „uzupełnieniem tego segmentu obrazu badanego pojęcia" ${ }^{4}$, pojęcie obrazu użyte zostaje $\mathrm{w}$ innym znaczeniu. Obraz słowa, językowy obraz pojęcia i inne podobne wyrażenia są z kolei odzwierciedleniem, jak sądzę, językoznawstwa, które, przy zachowaniu koniecznych cech dyscypliny, stara się w sposób holistyczny i humanizujący objąć swoją refleksją także "pozajęzykowe” fenomeny.

Jak wspomniałam, Sobstyl korzysta w swych analizach zarówno $\mathrm{z}$ danych zastanych, jak i wytworzonych: poddaje namysłowi kompleksy teoretyczne z zakresu nauk społecznych i humanistycznych, dane leksykograficzne - zarówno te dotyczące zakresów semantycznych leksemów, jak i ich użyć (aspekt pragmatyczny) - a także dane wytworzone. W kwestii badania jednostkowego użycia przedmiotowego leksemu na uwagę zasługuje konkluzja autorki, że mówić można o różnorodności indywidualnego obrazowania i o obrazach danego słowa, a nie o pojedynczym obrazie. Ta wielość, partykularyzm i akcentowanie indywidulanych użyć, kontekstów i profilowania przesądza zarówno o złożoności desygnatu, jakim jest samotność (przypomnijmy chociażby tytuł książki, który informuje o wielości takich obrazów: Samotność i jej obrazy w języku), jak i o szerokim spojrzeniu autorki, śmiało wychodzącym poza ramy językoznawstwa i zerkającym na obszar choćby kulturoznawstwa.

${ }^{3}$ Ibidem, s. 44; autorka przywołuje tu między innymi koncepcje G. Lakoffa, M. Johnsona, Ch. Fillmore'a czy R. Tokarskiego.

${ }^{4}$ Ibidem, s. 150. 
Czyniąc zadość rekonstruowanym tu pokrótce wątkom, nie można pominąć ostatniej części pracy, a więc tej, w której przedstawiono metodologię zbierania i analizowania danych: począwszy od opisów sposobów ankietyzacji (ściśle ilościowa metoda, ale uzupełniona - jeśli zaistniała taka konieczność - o rozmowę, nabierającą metodologicznie cech jakościowych) i związanych z nią problemów, poprzez szczegółową analizę uzyskanych od respondentów odpowiedzi, po ilościowe ich zestawienie i zobrazowanie $\mathrm{w}$ formie graficznej (diagramy). Wyłonienie respondentów wedle kryterium podstawowych danych socjodemograficznych (wiek, sytuacja psychospołeczna), wyróżnienie trzech grup badanych i zadanie im tych samych pytań pozwoliło autorce na dokonywanie interesujących zestawień (przedstawionych na przykład w tabelach) i porównań. Tak oto otrzymujemy językowe obrazy samotności młodzieży licealnej, dzieci zamieszkujących domy dziecka i osób starszych.

Całość monografii zdaje się uporządkowana, rozdziały i podrozdziały zostały jasno wyodrębnione, zbudowane wedle schematu: wstęp - rozwinięcie podsumowanie. Ważniejsze treści wyróżnione zostały graficznie za pomocą wytłuszczenia bądź wersalików. Zamieszczone w ostatniej części pracy rezultaty badań przeprowadzonych przez autorkę, ujęte w diagramy, wydrukowane zostały w kolorze, co znacznie ułatwia ich lekturę i czyni bardziej przystępnymi.

Reasumując, czytelnik otrzymuje książkę niezwykle interesującą, pozbawioną nużących rozważań i referowania po raz kolejny znanych teorii, zarówno tych z zakresu językoznawstwa, jak i tych dotyczących samej (sic!) samotności. Otrzymuje więc książkę świeżą, interesująco rozwijającą się w miarę czytania, aż do momentu kulminacyjnego, czyli przedstawienia wyników badań empirycznych. Humanistyczne „wycieczki” autorki świetnie uzupełniają leksykograficzne analizy i pozwalają połączyć w spójną całość stricte ludzki wymiar samotności (doświadczanie) z jej językowym wymiarem (wyrażanie). Dla językoznawców książka ta będzie z pewnością przyczynkiem do dalszych lingwistycznych analiz, dla humanistów uzupełnieniem badań lub - co ważniejsze i bardziej nobilitujące dla autorki - pretekstem do nowego spojrzenia na fenomen, który zdawali się już dobrze znać. 